\title{
Australian Museums, Aboriginal Skeletal Remains, and the Imagining of Human Evolutionary History, c. 1860-1914.
}

\author{
${ }^{*}$ Paul Turnbull
}

\begin{abstract}
Much has been written about how progress to nationhood in British colonial settler societies was imagined to depend on safeguarding the biological integrity of an evolutionarily advanced citizenry. There is also a growing body of scholarship on how the collecting and exhibition of indigenous ethnological material and bodily remains by colonial museums underscored the evolutionary distance between indigenes and settlers. This article explores in contextual detail several Australian museums between 1860 and 1914, in particular the Australian Museum in Sydney, the Queensland Museum in Brisbane, and the Victorian Museum in Melbourne, in which the collecting, interpretation and exhibition of the Aboriginal Australian bodily dead by staff and associated scientists served to imagine human evolutionary history.
\end{abstract}

Keywords: museum, collecting, human remains, Australia, Aboriginal, science, evolution

In 1887, Edward Pierson Ramsay, curator of the Australian Museum, wrote to Archibald Meston, a politically ambitious Queensland entrepreneur and journalist, living in the far northern township of Cairns. Meston rarely missed an opportunity to represent himself as the colony's pre-eminent expert on the life-ways and beliefs of its northern Aboriginal peoples. Hence Ramsay sought his help to procure the skeletal remains of the Ngadjon-Jii people, the traditional owners of the coastal rain forests to the south of Cairns. Meston replied, exclaiming in response to Ramsay's request, 'Re: skulls and skeletons of the festive myall!! To what strange uses are our noble primeval inhabitants to be put.'1

It was a typical rhetorical flourish by Meston, whose love of exaggerated prose, especially when describing his exploits as a pioneer northern explorer and anthropologist, was notorious. Typical too, was his ghoulish boasting to Ramsay that, at the prices the curator was willing to pay for skeletons and skulls, 'I could have procured about $£ 2000$ worth in the last six years...' - exclaiming '...I shall start on the warpath again! Hope to succeed in slaughtering some stray skeleton for you!'2

Meston had no intention of 'slaughtering some stray skeleton.' He was crassly alluding to the murderous frontier conflict then occurring in the far north of Queensland. He was in fact an outspoken critic in his journalism of the Native Police - the paramilitary force of Aboriginal men, led by white officers, which, as historian Jonathan Richards has shown, was responsible for numerous atrocities in the name of pacifying the Queensland frontier (Richards 2008). Meston wanted its disbandment, condemning the Native Police for killing 'for sport or slaughter gins [i.e. Aboriginal women] and picaninnies' - though, it must be noted, he held to the consensual view of the time, that securing northern Australia for white settlement invariably meant the violent suppression of Aboriginal resistance ${ }^{3}$

In terms of our understanding the context of Ramsay's soliciting the help of Meston, relevant historiography also confirms that there was nothing strange about the uses to which these remains would be put. Since Reynolds and Reece's pioneering mid-1970s research on racial thought in early colonial Australia (Reynolds 1974; Reece 1974), a substantial body of scholarship has drawn attention to how European scientific assumptions about the nature and origins of varietal differences in humankind proved fertile resources for the construal of Aboriginal people as inherently incapable of reasoning or moral judgement in any substantial, sustained way (Anderson 2007; Attwood 1989; McGregor 1997; Smithers 2009). 
In recent times, scholars have focused attention on how perceptions of Aboriginal people as evolutionary primitive types of humankind, determined by their environmental condition to express feeble powers of abstract conceptual thought, gained cognitive strength through the collecting, analysis and display of Indigenous material culture and skeletal remains by colonial museums under the impetus of evolutionary thought (Bennett 2004; Russell 2001; Turnbull 2008a, 2011). What were presumed to be peculiarities of Aboriginal morphology were construed by leading British metropolitan anatomists, most of whom were early converts to Darwin's arguments for evolution by speciation, as yielding important insights into the evolutionary genealogy of the human species (Desmond 1982).

Evolutionary scientists enlisted the help of Australian museum curators, local scientists and other colonial contacts in securing remains. For their part. Australian curators and scientists aspired to transcend what had hitherto largely been their status as collectors of raw scientific facts for export to metropolitan institutions. As Roy Macleod and Susan SheetsPyenson have shown, local curators and university-based researchers now sought to be producers of knowledge in their own right, active in metropolitan theorising and debate, while still acknowledging the leadership of authorities in British medico-scientific circles (Macleod 1982; Sheets-Pyenson 1988).

From their foundation in the mid-decades of the nineteenth century, the museums of Australia's colonial capitals cultivated networks of amateur natural history collectors who were geographically dispersed across much of rural and remote Australia (Griffiths 1996; Jones 1997, 2007; Robin 2001). Now they looked to these collectors, and also sought the assistance of police and other government agents in rural and frontier regions, to secure them Aboriginal remains, in the hope of systematically building their own osteological collections, and also providing specimens to give metropolitan scientists with whom they had shared intellectual interests, and, in many cases, patron-client ties (Morison 1997).

Aboriginal people lived as best they could, on mission stations, pastoral properties, or in squalid camps on the fringes of white settlement, while their dead were subject to plunder for museums as specimens of 'living fossils', supposedly confirming that, corporeally and psychologically, they were at a 'ground zero' of evolutionary development (Bennett 2004). What is more, as Bennett has argued, the collecting, analysis and exhibition of indigenous artefacts and skeletal remains served as resources for governmentality in the colonial state. They did so by heightening consciousness in the museum public of personal capacity for self-reflective action, and awareness of the self as archaeologically constituted. Grounded in the erroneous typological conceit that humanity comprised distinctive races, each with its own peculiar evolutionary biography and inheritance (Stepan 1982: 84; Stocking 1968: 1689 ), the didactic presence in museums of Aboriginal artefacts and bones served to confirm Australian settler society's destiny hinged on its pursuing higher levels of social and moral progress by intergenerational cultivation and transmission of its superior evolutionary capacity for self-enlightenment.

By the same token, as Bennett points out, the 'self' of Australia's original inhabitants was imagined to be '...flat, lacking in historical depth and complexity and, thereby, not affording the inner space in which a progressive dynamic might emerge from the work of self on self...' (Bennett 2004: 96). So construing Aboriginal psychology as evolutionarily bereft of significant potential for the care and cultivation of the self, museum personnel were complicit in what Johannes Fabian has termed a 'denial of coevalness' (Fabian 1983: 31-5) that, in imagining Aboriginal people as not having developed the psychological resources to negotiate the social and political complexities of the modern world, legitimated the creation and administration of protectionist regimes under which most lived by the turn of the twentieth century (Markus 1990; Haebich 2000; Kidd 1997).

This article does not substantially question this assessment of the operation and social effects of Australian museums. Rather, after documenting how leading Darwinian scientists inspired colonially-based collecting, analysis and display of Aboriginal skulls and other bodily remains, the article attempts to examine in contextual depth how a number of prominent museum curators, anatomists and anthropologists active between 1860 and 1914 materially and discursively rendered these relics sources for the cultivation of the colonial self.

Introducing this article with Archibald Meston's exchange with Edward Ramsay serves 
to illustrate the imaginative peculiarities in which skeletal material could become entangled in late nineteenth century Australian anthropological circles. Meston's ironic response betrays his sensing the moral fragility of settler identity. He was in fact to campaign vigorously for putting an end to frontier violence, and successfully lobbied to become one of the two first Protectors appointed under the Aboriginal Protection Act of 1897 - the legislation establishing the regime that, until well into the 1960s, subjected Aboriginal and Torres Strait Islander people within Queensland to government surveillance, regulation and control of virtually every aspect of their lives (Thorpe 1984; Kidd 1997).

There was also less irony in Meston's speaking of the nobility of northern Aboriginal people than we might think. Numerous popular anthropological articles he wrote for Queensland newspapers give thinly veiled expression to a desire for affective communion with an imagined pre-colonial Aboriginal past, which, in the early 1890s, was not only to see Meston stage, but also participate, bare chested in athletic tights, in 'Wild Australia' shows, lauding the natural physical prowess and hunting skills of northern Australia's 'noble primeval inhabitants' yet to experience the enervating effects of contact with white society (Walker 1997).

And yet, Meston was not bemused by Ramsay's wanting him to supply bones. He would have seen nothing strange in the curator approaching him. He understood their scientific value. Nor did he see any moral contradiction or offence in his plundering the burial places of the people whose primitive vitality he found so attractive. ${ }^{4}$

The examples of collecting and interpretation of skeletal material examined in this article are far less complex in terms of personal motivation; but in respect of intellectual intentions and ambitions, they nonetheless go some way to providing a more historically nuanced account of the uses to which Aboriginal remains were put in the century or so after 1860 . For one thing, they alert us to the continuing, albeit diminishing, influence of pre-Darwinian explanations of the nature and causes of varietal diversity seen in Aboriginal bones. But perhaps most importantly, looking more closely at the contexts in which evolutionary interpretations of Aboriginal morphology were made, affords important insights into how they spoke to contemporary hopes and fears for the emerging Australian nation.

As a number of scholars have shown, material and moral progress to nationhood in late nineteenth and early twentieth century Australia was widely envisaged as dependent on safeguarding the biological integrity and potential of an evolutionarily advanced white social body (Anderson 2002; Bashford 1998; Lake and Reynolds 2008). This belief in the fundamental importance of cultivating and protecting white racial vigour was reinforced by the experiences of Aboriginal people since European invasion being represented as exemplifying the dreadful consequences of racial failure (McGregor 1997). Christian and secular humanitarians laboured to convince the colonial public that Australia's 'native race' possessed a latent capacity for improvement that could be cultivated under European tutelage, enabling their gradual assimilation within the emerging European nation. But increasingly the consensus was that innate psychic differences condemned Aboriginal people to no future other than their paternal management in ever dwindling numbers by state and missionary enterprises.

Museum personnel and locally based scientists contributed to this shift by representing Aboriginal people to their public as primordial beings with scarce capacity for self-reflexivity (Bennett 2004: 5). Even so, this did not rule out committed evolutionists seeing in the skeletal morphology of Aboriginal people indications that they were capable of some measure of improvement. Indeed, as this article shows, their bones could be read as licensing the drawing of explicit parallels between the predicament of Aboriginal people in the wake of white settlement and the racial history of palaeolithic Europe - to the extent of imaginatively co-locating indigene and settler within a universal history, the moral being that the essential attributes and qualities of 'civilised man' had emerged through the struggles of higher racial types for supersession of less intellectually advanced races. This history, moreover, represented Aboriginal people as fated to be radically outpaced by virtually all other varietal types through their supposed entrapment in material conditions blocking their developing more sophisticated psychic resources. As such, this 'past beyond memory', in Bennett's memorable phrase (2004), offered a gloomy prognosis of the fate of Aboriginal people, while underscoring the need to safeguard the racial inheritance of the emerging Australian nation. 


\section{Evolution, museums and human remains: 'Savages, Fossil and Recent'}

Darwinian evolutionary theory gained rapid ascent in British scientific and wider intellectual circles during the 1860s, discursively transforming Aboriginal Australians into an evolutionarily primitive human type (Stocking 1987: 146-9; McNiven and Russell 2005: 5861). Darwinian anatomists and museum curators focused on securing skulls and what other bodily structures they could hope to obtain through colonial contacts. Thomas Henry Huxley was, understandably, among the first to solicit Australian remains. Among his contacts was the mining engineer and pioneer ethnographer Robert Brough Smyth, author of the compendious Aborigines of Victoria (1878), who had been secretary, then chair, of Victoria's Board for the Protection of Aborigines during the 1860s. Smyth could easily reconcile Darwinian racialism with administering a regime in which conversion to Christianity was generally thought an essential precondition for civilising the remnant of the colony's Aboriginal inhabitants. ${ }^{5}$ Nor did he have any qualms about trying to procure - very likely for Huxley - the skeleton of Derrimut, an Elder of the Boon Wurrung people, who was well known to settlers, and had been given Christian burial in Melbourne's general cemetery in 1863 (Clark 2005). ${ }^{6}$ Smyth also put Huxley in contact with Christopher D'Oyly H. Aplin, a surveyor with the Victorian Geological Survey Office, who in turn approached landowners on Huxley's behalf, securing him three skulls. ${ }^{7}$

Huxley also approached Gerard Krefft, curator of Sydney's Australian Museum. It was an obvious choice. Krefft, a zoologist, had come to Huxley's attention on describing a range of newly discovered Australian reptile and fish species in London scientific journals. Since his appointment as assistant curator, in 1860, he had also regularly sent vertebrate fossils to Richard Owen at the British Museum. However, Krefft was an admirer of Darwin, very likely having first read The Origin of Species as translated by Ernst Haeckel, Darwin's champion in German-speaking scientific circles.

In 1866, Krefft supplied Huxley with measurements of the museum's then modest collection of Aboriginal crania, promising to help him secure skulls through an amateur naturalist who had previously exhumed Aboriginal graves for the museum. ${ }^{8}$ However, Huxley's and other metropolitan anatomists' requests for skulls appear to have heightened Krefft's sense of the Australian Museum's potential to become, under his direction, a leading site for cranial and other avenues of anthropometric research on Australian and other Oceanic races. When, in 1872, Huxley approached Krefft wanting additional remains, and in particular female pelvic bones, Krefft deflected the request by sending Huxley photographs of skulls recently added to the Museum's collection. As for sending Huxley actual bones, Krefft wrote, 'I wish I could, but it is very difficult - we have 2 female skeletons in the museum but I cannot send them.' He further maintained that it was becoming increasingly rare to discover burial places, telling Huxley a collector employed by the Museum had been told 'a few days ago to look out for same', but 'I suppose the greater portion of the native graves are obliterated.' 9

In truth, Krefft over-accentuated the difficulties of procuring remains. Since his first contact with Huxley, the Museum had been actively collecting, acquiring four complete skeletons, around eighty skulls of Aboriginal and Oceanic origin, and was actively seeking more (Maddock 1874: 78). One of Krefft's first acts, on being promoted to curator in May 1864, had been to instruct the Museum's assistant, George Masters, to take remains from any burial places he discovered on collecting expeditions. ${ }^{10} \mathrm{Krefft}$ had also secured the help of amateur naturalists who had previously donated zoological specimens to rob graves. One of the first to oblige was a resident of central Queensland, who wrote to Krefft in September 1865 that he had not only 'got the bones of an alligator for you as soon as they are fit to send away' but 'also two black fellows buried in a paddock of mine on purpose to get the skeletons to send you.' ${ }^{11}$ How he had procured the bodies he did not say. In the same year, the Museum also received another two skeletons of central Queensland Aboriginal people from W.R. Davidson, a past student of the Oxford Darwinian anatomist, George Rolleston (NSW Parliament 1866: 4909).

The Museum's trustees were Anglicans or non-conformists. So while Darwin and Haeckel provided the impetus for Krefft's collecting, he was either required or thought it politic to display remains so as to illustrate Georges Cuvier and Richard Owen's anti-evolutionary biological functionalism (Outram 1984; Rupke 1994). Krefft's relations with the trustees were increasingly marked by irresolvable, personally debilitating disputes that ended with his 
dismissal in 1874 (Macinnis 2012). In the last year of his curatorship, he threw away caution. He had regularly used the Sydney press to cultivate popular interest in the natural sciences; now he wrote essays championing the Darwinians' vision of nature. One essay points to a personal interest in the Museum's skeletal holdings after participating in the excavation of a cave in the Wellington Valley of central-western New South Wales, in 1869, where what he took to be a fossilised human tooth was discovered (Campbell 1949). It proved a catalyst for his interpretation of the Museum's Aboriginal cranial material as having similarities not only with Neanderthal remains, but also the so-called 'Cro-Magnon' skeletons discovered in 1868 in the Vézère river valley in southwest France.

As Krefft learnt from reportage of the discovery by Paul Broca (1824-80), founder of the Parisian anthropological Society, these remains appeared to be those of a morphologically distinctive race, whose bodily characteristics bore no relation to remains found in ancient barrow mounds, or to modern Europeans. Broca hypothesised that this ancient race had undergone three distinct stages of societal development before sudden extinction. It seemed possible the Cro-Magnons had been intellectually outpaced and possibly wiped out by a more aggressive, technologically advanced race (Broca 1873: 426-8).

Possibly Krefft shared Ernst Haeckel's radical vision of nature, in which material biophysical forces alone had set processes of struggle and selectivity and determined the emergence in the human species of progressively superior racial types, with ever greater potential to achieve enlightenment (De Grood 1982). At any rate he immediately saw clear similarities between this drama of racial supersession played out in Europe's deep past, and that seemingly occurring in the Australian colonies. In an essay in the Sydney Mail in July 1873, Krefft wrote that 'Comparing the weapons of our savages with these descriptions of the learned Frenchman, we must acknowledge that he has hit the proper distinction to a point' (19 July 1873: 5). Western Australia, he maintained, was home to 'savages with scarcely any covering except a cape of wallaby skin, without possum rugs and with the roughest lump of granite embedded in grass-tree gum for a hatchet.' These people, he reasoned, were in these respects like the earliest Cro-Magnon race. Aboriginal people living along the Murray River and inhabiting coastal New South Wales were, in his estimation, 'more advanced.' Like later Cro-Magnons, they fashioned stone hatchets with ground edges and carved or drew hunting scenes. Finally, Krefft argued that that the inhabitants of New Guinea were modern counterparts to the Cro-Magnon race in the third and final phase of social development before its extinction.

For Krefft, Aboriginal people had progressed beyond an evolutionary ground zero. Like the Cro-Magnon race, they had achieved some measure of social and intellectual development. Even so, it seemed to him that Aboriginal capacity for improvement was still comparatively weak, compared to the Māori of Aotearoa New Zealand. Had they colonised Australia, he wrote, they 'would have made short work with our gentle savages' and 'given future invaders more trouble than they gave them in their limited islands, though even there they proved hard to conquer' (Sydney Mail, 19 July 1873: 5).

In this account of 'savages, fossil and recent', Krefft knowingly passed over Broca's arguing that the Cro-Magnon remains suggested that humanity had not evolved from one single earlier species (Schiller 1993: 11-12). The essay also suggests that like William Boyd Dawkins (1837-1929), the geologist and contemporary author of several popular accounts of European prehistory, Krefft believed some inherent law ensured that human evolution was socially and morally progressive in its outcomes. ${ }^{12}$

Tales of Blood and Mummies: The Queensland Museum

This vision of human history as fundamentally a drama of racial struggle, and the supersession of lower races, found blatant expression in the ways in which skeletal remains and weaponry were displayed in the Queensland Museum from around the early 1860s to the period when the museum moved into new, purpose-built premises in 1879-80. As one visitor in 1869 wrote at length in the Brisbane Courier:

Now, it has been shown how useful and instructive a study it is to compare the remains of a former world with this we now inhabit....[T]here are a great number of native instruments...collected and presented to the museum by many old colonists and explorers. Some...could tell a tale of blood, and the names of 
some of the former owners ...even now are never mentioned except with feeling of horror and abhorrence. This collection of spears and nullas were picked up after the Hornet Bank massacre, and that very large club belonged to a wellknown savage...the terror of the shepherds on the Kulebah and Goongarry; stone tomahawks from the Brown River...finger bones and a pair of defunct blacks...the spear...that finished poor Kennedy's career of exploration, with skulls of number of the most renowned blacks who were the terror of the first colonists, with short narratives of the dark deeds which marked the early days of Queensland. ${ }^{13}$

Here, one is struck by this visitor's describing this assemblage of weaponry and bones as relics of a 'former world' which by their presence brought into clear focus the hardships and dangers that were necessarily faced in securing the triumph of civilisation in the colony. One is also put in mind of Michael Taussig's observation, that the narrative creation of Indigenes as inherently 'savage' and 'deceitful' is characteristic of political economies of colonial violence where the natural brutality attributed to indigenous peoples mirrors the barbarous acts perpetrated by the colonists (Taussig 1987: 134).

Metropolitan anatomists and anthropologists also approached the Queensland Museum. I have written elsewhere of the efforts of George Rolleston, the Oxford Darwinian anatomist and protégé of Huxley, to exploit his colonial connections in order to procure Aboriginal remains (Turnbull 2011). Rolleston wrote in 1870 to the executive of the Queensland Philosophical Society, which then administered the Museum, appealing to both the cause of science and national honour. German museums, he warned, possessed 'as many as three or four [Aboriginal] skeletons', whereas he was not 'aware of more than three being in England at all (Queenslander 3 September 1870: 3). ${ }^{14}$ The trustees had Rolleston's letter published in the colony's most widely-read weekly newspaper, but did not offer any of the skeletal items they possessed, being intent on attempting to build its collection.

It was a similar story near a decade later when Claude-Joseph Désiré Charnay, a French archaeologist, was commissioned by France's ministry of public instruction to collect Australian specimens, and arrange exchange programs between the Queensland and Paris's natural history museum. He arrived in Brisbane having failed to obtain skeletal material in other colonies (Charnay 1881: 31). Learning that two Aboriginal men were shortly to be executed, Charnay asked the Philosophical Society's executive to help him secure their skeletons. They were agreeable, writing to Arthur Palmer, Queensland's colonial secretary, requesting that 'favourable consideration be given to the proposal. ${ }^{.15}$ By the time Palmer received the request, however, the two men had been reprieved.

Before travelling to far northern Queensland in early 1879, Charnay used Brisbane journalists to call for the Museum to be supported in advancing scientific investigation of the racial peculiarities of the colony's Aboriginal people. 'He is astonished', the Brisbane Courier reported, that 'we allow our native curiosities to be decently buried without bequeathing any legacy to science' (10 January 1879:2). Charnay's championing of the Museum's anthropological aspirations provoked the satirical comment in the Queenslander 'that we colonials...not allow a single blackfellow to go down to his grave with peace - at least with his headpiece'. ${ }^{16}$

Members of the Philosophical Society may have preferred no levity here, but they welcomed public recognition of the imperative to encourage collecting, having themselves been active persuading police, other government agents and settlers in the colony's outlying western and northern regions to obtain them remains (Turnbull 2008b).

Displays with jumbled weaponry and skulls celebrating the triumph of European civilisation over 'native savagery' were a feature of the Queensland Museum until it was rehoused in 1879-80, under the direction of the William Haswell, its first, full-time, scientifically trained curator. Haswell focused on presenting the Museum's geological and natural history collections within an evolutionary framework, before resigning soon after completing the relocation of the Museum. All we know of his use of remains was the prominent display of 'Queensland mummies' - the name given the bodies of Aboriginal people in the far north of the colony that had been subject to mortuary ceremonies involving lengthy processes of smoke drying and embalming. His successor, Charles de Vis, who was to be curator from 1882 to 1905, was an 
Anglican cleric who understandably construed scientific inquiry as promoting awareness of the attributes of God as expressed in the governance of nature. De Vis championed popular scientific education, school museum visits and Sunday openings for the benefit of working class families. Yet, he appears to have accepted that humankind was subject to evolutionary development. Like a number of influential liberal Anglican theologians and scientists he reasoned that Darwin had erred in hypothesising that evolution occurred by the blind operation of natural selection, believing that it was directed by divine intelligence to purposeful ends.

This may explain De Vis's relative lack of interest in displaying skulls, compared to his efforts to procure and display 'Queensland mummies', several of which continued to be on public view until the Museum moved to new premises in 1986. For as the press during De Vis's years as curator asserted, whenever it was feared one of these desiccated bodies might not be secured for the Museum, they were 'historical relics' of much importance, affirming in somewhat macabre terms the supposed distance in terms of social and moral progress between the Aboriginal and Anglo-Saxon races. ${ }^{17}$

A month or so before de Vis took up his curatorship, in March 1882, the museum trustees had declined to buy the 'mummy' of a young girl, which had been obtained by a party of armed settlers when raiding a camp of the Mbabaram people to the west of the far northern Queensland township of Herberton. The trustees had no qualms about how the remains had been procured, or the fact that the head of the girl indicated she had been shot dead in a previous raid. What they objected to was bargaining with the seller, who declared that he stood to gain an extremely high price for the corpse, were he to take it to Sydney or Melbourne and sell it himself. ${ }^{18}$

The Museum was again offered a 'mummy' the following year - that of a man of the Yidinyji-Malanbarra people stolen from a burial platform on the Mulgrave River, south of Cairns. This time, de Vis was quick to offer the seller $£ 5$, only to have him boast that the body was a 'very large one, being a King and Great Warrior', and that he could get a far higher price by selling it in England. This he had reason to think was possible, as there had been press reportage that this was so. ${ }^{19}$ Moreover, smoke-dried remains stolen from a burial tree just west of Cairns proved one of the most popular displays in the Queensland Courts of the Sydney and Melbourne International Exhibitions of 1879-81. This 'mummy', loaned to the exhibition commissioners by one of the men who stole it, was put up for sale in Sydney in 1884 for $£ 60$. Again, De Vis tried to buy it, and would have likely known that relatives of the dead man were deeply distressed by the theft of his remains. He also learnt that Edward Ramsay had offered $£ 20$ on behalf of the Australian Museum. ${ }^{20}$ The seller, however, declined both offers, eventually selling it at a higher price to an unknown buyer.

\section{The Evolutionary Anthropology of Walter Roth and Hermann Klaatsch}

The last years of the nineteenth century saw the entanglement of skeletal remains in government and public discourse over the future of the Queensland's Aboriginal people. This occurred with the appointment of two men to administer the regime created by the Aborigines Protection Act of 1897 who were also the Queensland Museum's most active donors of artefacts and skeletal remains. None other than Archibald Meston was appointed Protector of Aboriginal people in the southern half of the colony. The welfare of Aboriginal people in Queensland's north was entrusted to Walter Roth, attracted to the position by his keen interest in anthropology since studying human and comparative anatomy at Oxford in the mid-1880s (Reynolds 2008), with the naturalist Henry Nottidge Moseley (who, incidentally, had tried to obtain Aboriginal skulls for the Oxford Museum when visiting Sydney in 1874). ${ }^{21}$

Working as a government medical officer in northwest Queensland between 1894-7, Roth documented the life-ways and material culture of the region's Aboriginal people, gaining recognition by Edward Tylor and other leading metropolitan figures in the emerging discipline of anthropology (Roth 1897). His donations of artefacts and friendship with politically influential museum trustees not only led to his appointment as Protector, but also helped convince the colony's government that his duties should include recording the traditional beliefs and cultural practices of Aboriginal peoples across its vast northern regions, as a vital contribution to science, but also knowledge of practical value in managing the destiny of Aboriginal people. 
Until his resignation in controversial circumstances in 1906, Roth produced a series of detailed ethnographic reports (Roth 1984), and supplied the Queensland Museum around 200 artefacts from central and northern parts of the colony (Rowlands 2010: 267). He also amassed data on the supposed evolutionary peculiarities of northern Aboriginal people. During his first two and half years as Northern Protector, he methodically took physical measurements, photographs and thumb prints, reporting in mid-1900 that on the basis of 'over 2,000 distinctive measurements' he had compiled fifty anthropometric charts, 'illustrative of the different types of men and women to be met with in the North' (Roth 1900: 593). In doing so, Roth used the system devised by Alphonse Bertillon, the contemporary Parisian criminologist, to identify recidivist criminals - thus simultaneously benefitting anthropology and the state's power to police Aboriginal people.

Unsurprisingly, Roth rarely missed a chance to collect skeletal remains. During his time as a government medical officer, he took advantage of the deaths of Native Police troopers and other Aboriginal people under his care.22 Among the first items he offered the Queensland Museum, in late September 1897, was the complete skeleton of an Aboriginal man, possibly one such police trooper.

Roth also brought the Museum's collections to the attention of metropolitan scientists and, as Protector, used what resources his office allowed to assist other local scientists and metropolitan visitors to travel to rural and remote parts of Queensland. Among the most influential investigators of the Museum's holding he helped was the German comparative anatomist Hermann Klaatsch. Arriving in Brisbane in March 1904, Klaatch sought to investigate whether the morphology of Queensland's Aboriginal people might confirm, as Otto Schoetensack (a Heidelberg colleague) believed, that Australia's indigenous inhabitants were not descended from prehistoric migrants, but that the continent had been the site of the human genus having evolved from a pithecoid ancestral form, when the continent was part of a larger landmass. This would explain, Schoetensack reasoned, why darker skinned races with much the same bodily characteristics were to be found in regions encircling the Indian Ocean (Klaatsch 1908: 160).

In seeking anthropometric data to test this hypothesis, Klaatsch frequently and skilfully excited the interest of Australian journalists. Arguably no scientist in the first years of the twentieth century - with the possible exception of Baldwin Spencer - gave more interviews, talks and lectures, in both urban and regional centres, which drew popular attention to the study of Aboriginal morphology and the rationale for museums and other scientific institutions collecting remains. He took every opportunity to stress that this was likely the last opportunity to study the 'evolution of the genus homo....in relation to the original type from which he sprang.' Queensland's Aboriginal population was, Klaatsch lamented, 'fast drifting into the condition of civilisation, in which their value from my point of view evaporates.' ${ }^{23}$

After several weeks meticulously examining the Queensland Museum's crania, Klaatsch set out for far northern Queensland, where, with Roth's assistance, he attempted, with mixed success, to obtain anthropometric data and bones of Aboriginal people still living traditionally on islands in the Gulf of Carpentaria, or supposedly close to their 'wild state' on the coastal missionary settlements of Mapoon, Arakun and Yarabah, to which most far northern Aboriginal people had by this time been forcibly moved. He proved ruthless in trying to secure skeletal material, on one occasion escaping death at the hands of relatives of a man whose grave he was caught plundering (Erkenbrecht 2010: 89).

One of two visits Klaatsch made to the Anglican mission station of Yarrabah coincided with the arrival in Cairns of Gilbert White, the Bishop of Carpentaria. White later recalled that the anatomist had 'asked that the natives might be sent to him in order that he might measure their skulls' and 'sat accordingly on the veranda with a big pipe and measured the skulls of all who came, and the more he measured the more he shook his head'. According to White, this troubled the Reverend Ernest Gribble, Yarrabah's superintendent:

'Will you not come into the school and examine the children?' said the superintendent. 'They have made remarkable progress, and up to the age of eleven do the same lessons as the children in the white schools.' 'No,' said the Professor, 'I do not want to see them. I know that they are incapable of learning anything. I have measured their skulls.' 'But will you not look at our steam-engine, 
which is run entirely by two aboriginal boys?' 'No,' was the reply. 'They cannot possibly understand machinery. I have measured their skulls.' 'But,' persisted the superintendent, 'will you not at least listen to our band, which is often in requisition when good music is required in Cairns?' 'No,' was the reply. 'It is no good. I have measured their skulls' (White 1918: 158-9).

White's account should be read in the light of the extensive press coverage that Klaatsch enjoyed during his anthropological journeying. White probably did not directly witness the exchange between the Reverend Gribble and Klaatsch; but he nonetheless accurately captured its tenor. After the anatomist left Yarrabah, Gribble was quick to publicly defend his mission, declaring that 'Professor Klaatsch may be an accredited scientist, but as he only spent his time indoors examining heads and asked for no other examination whatever, I fail to see how he has come to the conclusions he has. ${ }^{24}$ Klaatsch, for his part, regarded missionary endeavour as 'exaggerated humanitarianism, which sees brothers and sisters in all the lower races,' (Klaatsch and Heilborn 1920: 91; 1923: 107). The press widely reported his dismissing Christianising and training Aboriginal people as rural workers as futile, indeed cruel, believing that they would be extinct before experiencing any significant improvement. As he told one reporter before leaving Australia, 'No matter how you may educate them, they will sure enough, sooner or later, go back to their natural state. They cannot help it, if they would. It is in them and nothing will stop it.' 25

Klaatsch held that true humanitarians would put Aboriginal people under scientifically based management of their destiny. Missionaries, he conceded, had a role to play in providing humane care to those forced by white ambition from their ancestral country, until reproductive failure caused their extinction. For Aboriginal people yet to experience sustained contact with settler society, there was hope, if large reserves were created in central and northern Australia, wherein they could live in total isolation, as they had supposedly done before the coming of the white people. ${ }^{26}$ This was, in effect, the entertainment on an ambitious scale of the anthropological fantasy played out in the European metropole through 'native villages' featured in international expositions in the second half of the nineteenth century, which documented the essential traits of a racial type (Qureshi 2011).

White and Gribble's reactions testify to the concerns felt by many Churchmen by the turn of the twentieth century time about scientific circumscription of Aboriginal peoples' capacity for improvement. They had done much to persuade the government to establish a protective regime by highlighting the plight of Aboriginal people forced from their ancestral country into fringe camps on the edges of northern settlements. They saw themselves as divinely charged to provide spiritual guidance and education enabling the remnants of the Aboriginal race to learn to live independently by agrarian labour within settler society. Hence they were understandably worried that the racially determinist ideas and arguments of scientists like Klaatsch were reaching a wide audience, and would increasingly gain credence in government circles. Roth, for example, as Protector, was generally on good terms with northern missionaries, but he made no secret that he regarded the Aboriginal people as evolutionarily incapable of improvement, and likely doomed to extinction.

\section{The Evolutionary Museology of Edward Charles Stirling and Walter Baldwin Spencer}

The similarities that Darwinian anatomists saw between the cranial morphology of Neanderthal and Aboriginal Australians were also the stimulus for the South Australian and Victorian Museums taking a focused interest in collecting skeletal material. I have written elsewhere of how Edward Charles Stirling, director of the South Australian Museum between 1884-1912, regarded Aboriginal crania and tibia bones as exhibiting clear points of resemblance with those of palaeolithic Europeans (Turnbull 2011: 116-9). By the mid-1890s, these resemblances were a focal point of the museum's arrangement of skeletal remains illustrating the course of human evolutionary development and racial branching since the palaeolithic era.

Stirling also gave talks on these resemblances. For example, in September 1893, he gave a public lecture on 'Primitive Man' in conjunction with the meetings in Adelaide that year of the Australasian Association for the Advancement of Science. ${ }^{27}$ In the lecture, reported substantially in the Adelaide press, and soon after published in pamphlet form, Stirling argued 
that the degree of typically Neanderthaloid cranial characteristics and flattened tibia in Aboriginal people was such that he could confidently assert that Australian settlers had about them '...in the Aboriginal races an almost exact counterpart of the most ancient men [in Europe] whose remains have come to light during recent years' (Stirling 1893: 2). What is more, Stirling was moved to sketch, much as Gerard Krefft had done twenty years before, life in the palaeolithic life era as characterised by the successive displacement, and likely extermination, of racially distinct peoples by physically and intellectually superior types. Stirling was also similarly drawn to conclude that, not only were the peoples of the late European palaeolithic era possibly 'overwhelmed and annihilated by....advancing hordes of neolithic invaders,' but also that this ancient racial antipathy had its modern analogue, in 'the same feelings as have always existed between the Eskimos and Red Indians, terror and defenceless hatred being met by ruthless extermination.' 28

The construal of Aboriginal people as at 'evolutionary ground zero' was to find its most explicit and influential expression in the direction of the National Museum of Victorian by Walter Baldwin Spencer. When Spencer assumed its directorship, in 1899, the museum was at anthropological ground zero. His predecessor, Frederick McCoy, had been both resolutely anti-Darwin and uninterested in ethnology during his near forty year tenure. ${ }^{29}$ Occasional donations of Aboriginal skulls had been received, mostly from medical practitioners living in Victorian country towns; but they had been passed on to George Britton Halford, Melbourne university's first professor of anatomy, and McCoy's ally in publicly challenging the scientific basis of Darwinians' efforts to reconstruct human evolutionary genealogy (Butcher 1988). If they were then put to any purpose, it was in teaching Melbourne students the evidential strength of Cuvier and Owen's explanations of human variation.

One of Spencer's first actions was securing space for exhibiting Aboriginal weapons, implements and ceremonial objects, starting with items from small collections of Australian and Pacific artefacts acquired by the Victorian government after merging Melbourne's Industrial and technological Museum with the National Museum. As Mulvaney and Calaby have shown, he took 'Aborigines from the human context of comparative technology, and reclassified them firmly amongst the flora and fauna of a natural history museum' (Mulvaney and Calaby 1985: 247). Employing the evolutionary typology of Oxford's Pitt Rivers Museum, he had artefacts displayed to illustrate the 'successive ideas by which the minds of men in a primitive condition of culture have progressed in the development of their arts from the simple to the complex, and from the homogeneous to the heterogenous.' The initial centre-piece of the museum's Australian gallery was a series of boomerangs 'exhibited...to illustrate the various forms and the possible development from a straight stick of...the return boomerang' and throwing clubs (Spencer 1914: 23-24).

Spencer's anxiousness to begin systematic collecting of artefacts proved a further incentive for his embarking on fieldwork with Aboriginal people between Oodnadatta and Borroloola in 1901-2 (Mulvaney and Calaby 1985: 188). He also wanted the museum to play a leading role in the study of the evolutionary inheritance of people he imagined to 'still remain on the cultural level of the stone age'. Besides taking anthropometric measurements and photographs, Spencer also had skeletal material removed from burial places. Harry Chance, an ex-mounted policeman serving as driver and cook, saw but chose not to take remains from a tree burial encountered near the Ti Tree Telegraph Reserve, about 190 kilometres north of Alice Springs. Gillen recorded with characteristic joviality in his journal, that

Had we seen the grave we should have bagged the bones and added them to our collection. Chance severely reprimanded for not at least laying violent hands on the skull and so that there may be no repetition of such remissness he is promptly and solemnly appointed Chief body snatcher to the Expedition (Gillen 1901-2: 158).

After returning to Melbourne, in March 1902, Spencer participated in excavating graves discovered near Koondrook on the confluence of the Murray and Loddon Rivers in north western Victoria. This was to be the first of numerous first-hand investigations of pre-colonial sites of Aboriginal habitation in Victoria, and other parts of south eastern Australia, through which skeletal material came to the Museum. 
Another source Spencer exploited was Victoria's Field Naturalists Club, of which he was president for much of the 1890s. One Club member donated over twenty skulls and various post-cranial items dug out of eroded banks of the Murray and Loddon Rivers in 1905. ${ }^{30}$ Another prominent member of the Club supplied remains for the museum from 1907 to the mid-1930s. ${ }^{31}$ This was Alfred S. Kenyon, a civil engineer, whose interests in Aboriginal art and stone tools have been perceptively explored by Tom Griffith. Spencer adopted Kenyon's mode of classifying stone tools in displaying them, believing that it showed with particular clarity how the effectiveness of the technology of Aboriginal people was constrained by their supposed environmental entrapment in evolutionary stasis (Griffiths 1996: 67-85).

Spencer's evolutionary museology was to influence otherAustralian museum personnel of the early twentieth century. Robert Etheridge Junior, who succeeded Edward Ramsay as curator of the Australian Museum in Sydney, looked to Spencer when creating a department of ethnology in 1906. Ronald Hamlyn-Harris, who took charge of the Queensland Museum in 1910, re-modelled the displays of Aboriginal artefacts and bodily remains, emulating Spencer in commissioning a life-size diorama representing a supposedly typical Aboriginal family of Queensland - using duplicates of the figures commissioned by Spencer. ${ }^{32}$ The effect, as Lynette Russell has observed of the Melbourne diorama, was to objectify and erase any sense of localised cultural specificity for museum visitors, thereby accentuating the effect of adjacent displays of artefacts and skeletal remains situating Aboriginal people as frozen in primordial time (Russell 2001: 46-7).

\section{Conclusion}

Considerably more could be said about the uses Australian museum personnel put skeletal remains to, and the scientists with whom they interacted, from the 1860 s to the eve of the First World War. However, what has been presented here shows that there is more to learn about how remains were employed in colonial museums to articulate of the evolutionary fate of Aboriginal people. The historical layering of self that Bennett points to was a principal contribution of museums to governmentality in the Australian colonial context, a process which occurred in some contexts where didactic, imaginative parallels were drawn with palaeolithic Europeans. Alternatively, as exemplified by Hermann Klaatsch, Australia could be hypothesised as an 'evolutionary ground zero' from which both Aboriginal people and Europeans had arisen. It also seems that by the turn of the twentieth century, Aboriginal people were seen as being in so primitive a phase of evolutionary development as to deter plausible parallels being drawn with the prehistory of Europeans. All these complexities invite closer contextual scrutiny by scholars, to explore further the ways in which the bones of Aboriginal people proved a potent ingredient in the workings of governmentality in late nineteenth and early twentieth-century Australia.

Received: 2 September 2013

Finally accepted: 15 January 2015

\section{Notes}

1 A. Meston to Ramsay, 15 March 1887. Papers of Edward Pierson Ramsay. MS 1589/2/193. Mitchell Library, Sydney (ML). The term 'myall' entered the colonial Australian vocabulary in the 1830s. It was used to describe Aboriginal people still living traditionally who understandably violently resisted white settlers invading their country.

2 Meston to Ramsay, 15 March 1887. ML.

3 Brisbane Courier 27 September 1884: 3.

4 Charles de Vis to Minister of Public Instruction, 10 October, 1893. Outwards Correspondence, 93/4260. Queensland Museum Archives, Brisbane (QM); B. Purcell to Trustees, 17 March 1893. Letters Received 1889-1920, 9/P 1889-1910. Australian Museum Archives, Sydney (AM). 
5 Notes and Lectures, Papers of Robert Brough Smyth, 1856-1889. MS 8781/2. State Library of Victoria Melbourne (SLV). In his lecture to the Bendigo Working Men's Club of 1886, Smyth argued that Providence had bestowed on man two books of supreme wisdom: the Bible and The Origin of Species.

6 Smyth, MS 8781, Box 1176/1. SLV. This fragment of a letter was drafted by or for William Thomas (1793-1867), then Victoria's Guardian ofAborigines, concerning exhuming Derrimut's remains. Thomas was agreeable only to his skeleton being measured and photographed on the understanding it was reburied. Huxley is not named as the intended recipient of either the remains or resulting data, but the timing of the request strongly suggests that Smyth was acting at his request.

7 Huxley Papers, Series 18. Scientific Notebooks, Papers and Correspondence, Notes and Correspondence Notebook, Anthropology, Vol. 2, c. 1865-1875. Box 16, series 18/143. Imperial College Archives, London (IC).

8 F. Wilcox to McCoy, 29 March 1865. Correspondence 1854-99, Box W-Z. Ethnohistorical Section, Museum Victoria, Melbourne (MV).

9 Krefft to Huxley, 30 December 1872. Huxley Papers, General Correspondence, Box 19 Series $1 \mathrm{k} . \mathrm{IC}$.

G. Masters to Krefft, 23 May 1865. Correspondence Series 14: Letters Received Pre-1883, Box 1, C: 40.65.5. AM.

11 J. Nobbs to Krefft, September 1865. Correspondence, Series 7: Letters Received, 185383. AM.

12 On the spectrum of teleological interpretations of Darwin's argument, see Desmond 1982: $175-86$.

Brisbane Courier 28 August 1869: 6. Queenslander 3 September 1870: $3 .$.

Museum Trustees to Colonial Secretary, 9 January 1879. Inward Correspondence - Colonial Secretary, 5253/114. Queensland State Archives, Brisbane.

Brisbane Courier 18 January 1879: $81 .$.

Queenslander 17 January 1880: 82.

F. Lyons to Curator, MS 1589/4, 9-12. ML.

Queenslander 17 January 1880: 82; Kapunda Herald 4 February 1881: 3.

De Vis Junior to De Vis, 2 February 1885. Inwards Correspondence 1885. QM.

Rolleston, Miscellaneous Archaeological and Anthropological Letters and Papers', Box 4. AMO.

Items E. 15155 -274; E. 16395-97, Roth Collection Register 1905. AM.

Rockhampton Morning Bulletin 25 March 1904: 5.

Cairns Morning Post, 10 February 1905: 3..

Western Mail 7 October 1905: 45 ). 


\section{References}

Anderson, K. (2007) Race and the Crisis of Humanism, Oxford: Routledge.

Anderson, W. (2002) The Cultivation of Whiteness: Science, Health and Racial Destiny in Australia, Melbourne: Melbourne University Press.

Attwood, B. (1989) The Making of the Aborigines, Sydney: Allen and Unwin.

Bashford, A. (1998) Quarantine and the Imagining of the Australian Nation, London: Sage Publications.

Bennett, T. (2004) Pasts Beyond Memory: Evolution, Museums, Colonialism, London: Routledge.

Broca, P. (1873) 'The Troglodytes of the Vezere', Nature, 7 305-8.

Butcher, B. (1988) 'Gorrila Warfare in Melbourne: Halford, Huxley and Man's Place in Nature', in R.W. Home (ed) Australian Science in the Making, Cambridge: Cambridge University Press, 153-69.

Campbell, T. (1949) 'The Krefft Tooth - is it a Human Molar?', Records of the Australian Museum, 22(2) 200-6.

Charnay, D. (1881) 'Rapports sur une mission dans l'île de Java et en Australie', Archives des missions scientifiques et litteraires, 7 21-38.

Clark, I. (2005) "You have all this place, no good have children": Derrimut: Traitor, Saviour or a Man of His People?', Journal of the Royal Australian Historical Society, 91(2) 107-32.

De Grood, D. (1982) Haeckel's Theory of the Unity of Nature: a Monograph in the History of Philosophy, Amsterdam: B.R. Gruner.

Desmond, A. (1982) Archetypes and Ancestors: Palaeontology in Victorian London 18501875, London: Blond \& Briggs.

Erkenbrecht, C. (2010), Auf de Suche nach den Ursprüngen. Die Australienreise des Anthropologen und Sammlers Hermann Klaatsch 1904-1907, Cologne: Wienand Verlag. 
Fabian, J. (1983) Time and the Other: How Anthropology Makes its Object, New York: Columbia University Press.

Gillen, F. (1901-2) 'Camp Jottings. A Modest Record of Our Doings Day by Day, Volume 1', MS PRG 54, State Library of South Australia: Adelaide.

Griffiths, T. (1996) Hunters and Collectors: the Antiquarian Imagination in Australia, Melbourne: Cambridge University Press.

Haebich, A. (2000) Broken Circles: Fragmenting Indigenous Families 1800-2000, Fremantle, W.A.: Fremantle Arts Centre Press.

Jones, P. (1997) '"A Box of Things": Ethnographic Collectors and the South Australian Museum, 1830 - 1930', PhD, University of Adelaide.

(2007) Ochre and Rust: Artefacts and Encounters on Australian Frontiers, Adelaide: Wakefield Press.

Kidd, R. (1997) The Way We Civilise: Aboriginal Affairs - the Untold Story, Brisbane: University of Queensland Press.

Klaatsch, H. (1908) 'The Skull of the Australian Aboriginal', Reports from the Pathological Laboratory of the Lunacy Department, New South Wales Government, 1(3) 44-167.

and Heilborn, A. (1920) Der Werdegang der Menschheit und die Entstehung der Kultur, Berlin: Bong and Co.

(1923) The Evolution and Progress of Mankind, London: T. Fisher Unwin.

Lake, M. and Reynolds, H. (2008) Drawing the Global Colour Line: White Men's Countries and the International Challenge of Racial Equality, Melbourne: Cambridge University Press.

Macinnis, P. (2012), Curious Minds. The Discoveries of Australian Naturalists, Sydney: National Library of Australia.

Macleod, R. (1982), 'On Visiting the Moving Metropolis: Reflections on the Architecture of Imperial Science', Historical Records of Australian Science, 5(3) 1-16.

McGregor, R. (1997) Imagined Destinies: Aboriginal Australians and the Doomed Race Theory, 1880-1939, Melbourne: Melbourne University Press.

McNiven, I. and Russell, L. (2005) Appropriated Pasts: Indigenous Peoples and the Colonial Culture of Archaeology, Lanham, MD: Alta Mira Press.

Maddock, W. (1874) Visitor's Guide to Sydney..., Sydney: W. Maddock.

Markus, A. (1990) Governing Savages, Sydney: Allen \& Unwin.

Morison, P. (1997) J. T. Wilson and the fraternity of Duckmaloi, Amsterdam: Rodopi.

Mulvaney, D. and Calaby, J. (1985) 'So Much That is New'. Baldwin Spencer: a Biography, Melbourne: Melbourne University Press.

New South Wales (NSW) Parliament (1866) Votes and Proceedings of the Legislative Assembly, Sydney: Government Printer.

Outram, D. (1984) Georges Cuvier: Vocation, Science, and Authority in Post-revolutionary France, Manchester: Manchester University Press. 
Qureshi, S. (2011) Peoples on Parade: Exhibitions, Empire, and Anthropology in Nineteenth-century Britain, Chicago: University of Chicago Press.

Reece, R. (1974) Aborigines and Colonists: Aborigines and Colonial Society in New South Wales in the 1830s and 1840s, Sydney: Sydney University Press.

Reynolds, B. (2008) 'The family Background and Achievements of Walter Edmund Roth', in R. McDougall and I. Davidson (eds), The Roth Family, Anthropology and Colonial Administration, Walnut Creek, CA: Left Coast Press, 41-58.

Reynolds, H. (1974) 'Racial Thought in Early Colonial Australia', The Australian Journal of Politics and History, 20 (1) 45-53.

Richards, J. (2008) The Secret War: a True History of Queensland's Native Police, Brisbane: Queensland University Press.

Robin, L. (2001) The Flight of the Emu: a Hundred Years of Australian Ornithology 19012001, Melbourne: Melbourne University Press.

Roth, W. (1897) Ethnological Studies Among the North-West-Central Queensland Aborigines, Brisbane: Government Printer.

(1900) 'Report of the Northern Protector of Aboriginals for 1899', Queensland Parliament Votes and Proceedings, 5 (2) 580-95.

(1984) The Queensland Aborigines, Victoria Park, W.A.: Hesperian Press.

Rowlands, S. (2010) 'The Manufacturers: Collection, Display and Aboriginality at the Queensland Museum from the Late Nineteenth to the Early Twentieth Century', PhD thesis, Doctor of Philosophy, University of New England.

Rupke, N. (1994) Richard Owen: Victorian Naturalist, New Haven: Yale University Press.

Russell, L. (2001) Savage Imaginings: Historical and Contemporary Constructions of Australian Aboriginalities, Melbourne: Australian Scholarly Publishing.

Schiller, F. (1993) Paul Broca : Founder of French Anthropology, Explorer of the Brain, New York: Oxford University Press.

Sheets-Pyenson, S. (1988) Cathedrals of Science: the Development of Colonial Natural History Museums during the late Nineteenth Century, McGill-Queen's University Press.

Smithers, G. (2009) Science, Sexuality, and Race in the United States and Australia, 1780s-1890s, New York: Routledge.

Spencer, W. (1914) Guide to the Australian Ethnological Collection in the National Museum of Victoria, Melbourne: Government Printer.

Stepan, N. (1982) The Idea of Race in Science: Great Britain 1800-1960, London: Macmillan.

Stirling, E. (1893), Prehistoric Man, Adelaide: Privately Printed.

Stocking, G. (1968) Race, Culture and Evolution: Essays in the History of Anthropology, Chicago: University of Chicago Press.

(1987), Victorian Anthropology, New York: Free Press. 
Taussig, M. (1987) Shamanism, Colonialism, and the Wild Man: a Study in Terror and Healing, Chicago: University of Chicago Press.

Thorpe, W. (1984) 'Archibald Meston and Aboriginal Legislation in Colonial Queensland', Historical Studies, 21 (82) 52-67.

Turnbull, P. (2008b) 'Theft in the Name of Science', Griffith Review, 21, 227-33.

(2011) 'A Judicious Collector: Edward Charles Stirling and the Procurement of Aboriginal Bodily Remains in South Australia, c. 1880-1912', in S. Ferber and S. Wilde (eds) The Body Divided: Human Beings and Human 'Material' in Modern Medical History, London: Ashgate, 109-30.

Walker, F. (1997) 'The Reinvention of the 'Noble Savage': Archibald Meston and "Wild Australia"', Bulletin (Olive Pink Society), 9(1-2) 38-43.

White, G. (1918) Thirty Years in Tropical Australia, London: Society for the Propagation of Christian Knowledge.

*Paul Turnbull is Professor of Digital Humanities at the University of Tasmania. He has written extensively on evolutionary science, racial anatomy and the use of Indigenous Australian bodily remains. His most recent publications include the co-edited volume, The Long Way Home: the Meanings and Values of Repatriation (Berghahn, 2011).

Paul is currently a chief investigator on a major Australian Research Council research project, 'Repatriation, Reconciliation and Renewal', which aims to investigate the history and cultural significance of the repatriation of ancestral bodily remains of Indigenous Australians from scientific collections.

School of Humanities

Faculty of Arts

University of Tasmania, Launceston

Locked Bag 1340

TAS 7250

Australia

Tel: +61 (0)3 6323056

Mob: 0408441139

Email: paul.turnbull@utas.edu.au 